Marquette University

e-Publications@Marquette

College of Education Faculty Research and

Publications

Education, College of

$1-1-2019$

The Diversity Distraction: A Critical Comparative Analysis of Discourse in Higher Education Scholarship

Derria Byrd

Marquette University, derria.byrd@marquette.edu

Published version. Review of Higher Education, Vol. 42, No. N/A (2019) : 135-172. DOI. (C) 2019

Johns Hopkins University Press. Used with permission. 


\title{
The Diversity Distraction: A Critical Comparative Analysis of Discourse in Higher Education Scholarship
}

\author{
derria byrd
}

\begin{abstract}
This critical literature review investigates how "diversity" and "equity" are employed in top-cited higher education scholarship published between 2000 and 2015. No analysis to date has offered such a comparative exploration relative to well-recognized racial disparities in higher education. Findings reveal a divergence with "diversity" largely attending to affirmative action concerns and "equity" to analyses of the pursuit of equity in higher education. The article concludes with advocacy for the equity frame because
\end{abstract}

derria byrd is an Assistant Professor of Educational Policy and Leadership in the College of Education at Marquette University in Milwaukee, WI. Her primary research interest is in educational equity with higher education. Her research focuses on the factors that facilitate and constrain organizational change on behalf of and by marginalized populations in higher education, with a particular interest in the role of culture and power in these transformations.

Author Note: The research, writing and revision of this manuscript was supported in part by an Advanced Opportunity Fellowship offered as part of the University of Wisconsin-Madison School of Education Graduate Research Scholars program, and by the National Academy of Education/ Spencer Dissertation Fellowship Program. In addition to being grateful for the support of the Black Power! Writing Collective and critical friend Dr. Shameka Powell, the author would like to thank the anonymous reviewers whose input helped shaped this manuscript.

Correspondence concerning this article should be addressed to derria byrd, Marquette University, College of Education, P.O. Box 1881, Milwaukee, WI 53233. Contact: derria.byrd@ marquette.edu. 
of its presumption of a normative justice-oriented standard and embedded orientation toward inquiry and action, both of which offer greater promise for policy, practice, and research that aim to enhance racial justice in higher education.

\section{The Diversity Distraction: ${ }^{1}$ \\ A Critical Comparative Analysis of Discourse in Higher EDUCATION SCHOLARSHIP}

Acknowledgement of ongoing and increasing disparities experienced by students from marginalized backgrounds has led to rising concern about equitable educational access and outcomes for these populations as well as about appropriate responses to these realities (Dowd \& Bensimon, 2015; Quaye \& Harper, 2014). This relatively new attention to equity in educational opportunity in higher education exists alongside a more established concern about - and pursuit of — diversity in higher education, which often emphasizes numerical representation of particular groups within and across higher educational contexts and programs (Tienda, 2013). Despite the co-existence of these varied but related frames within higher education scholarship and practice, no analysis to date has offered a comparative exploration of the content of these frames relative to the well-recognized disparities in higher education access and success. Further, given that many of these long-standing disparities are faced by students from populations marginalized in terms of race and ethnicity, the relative efficacy of these frames in examining and promoting efforts toward increased racial justice in higher education is of relevance to scholars and practitioners.

Diversity and equity frames appear to have emerged from different impulses; however, with relatively little investigation into the content of these frames, it is difficult to assert whether this is a semantic or a substantive distinction. The purpose of the current analysis is to present such an examination. It offers a critical content analysis of top-cited higher education scholarship published between 2000 and 2015 in an effort to document the content of "diversity" and "equity" frames in higher education scholarship as well as their application to concerns about justice for racially marginalized college students. Such an examination can offer a useful guide for future

${ }^{1}$ After conceptualizing this paper with the given title, I encountered "Diversity's Distraction," an article written by Derrick Bell (2003), a prominent legal and critical race scholar. While Bell's central critique is similar-that diversity acts as a distracting sleight-of-hand in the work of addressing racial inequity - the brunt of his argument focuses on conceptions of merit that limit access to higher education for minoritized students based on race as well as on class. 
programming, policy, and scholarly efforts focused on racial justice in higher education. After contextualizing the emergence of the diversity and equity frames in higher education, this paper presents findings from a critical examination of relevant scholarship. Given the challenges observed with the diversity frame, the paper concludes with a discussion of the implications and challenges of the equity frame-theoretically, empirically, and practically-and its potential to support the pursuit of racial justice in higher education through scholarship and practice.

\section{Diversity and Equity in Higher Education}

The literature on diversity in higher education informs that the 1990s brought a shift away from a concern for equality (Ahmed, 2012; Oswick, 2010). The equality concern had spawned from the affirmative action and equal employment opportunity movements of the 1970s and 1980s, and had waned in the face of limited enforcement and a generalized fatigue (Kelly \& Dobbin, 1998). By the 1990s, concern focused on understanding, honoring, and melding cultural difference in service of racial harmony-the beginning of the diversity revolution (J. M. Bell \& Hartmann, 2007). While "diversity" may have evolved to mean something more-or at least something different-for many it was merely a new spin on affirmative action, not a new concept but a new rhetoric. Winbush (2004) states more bluntly the anticipated effect of this rhetoric:

Affirmative action became two dirty words in a country that felt it had given its ex-slaves, women, and other protected groups enough time to get themselves together on issues of equality. A more palatable term would be necessary ... $[W]$ e would see the word "diversity" flexing its muscles as the term of choice when discussing affirmative action. Like a sedative slipped into the glass of an unsuspecting person, it lulled people into a dream-like sleep about affirmative action; it became the fashionable way to express the inevitable change that would take place on university campuses. (p. 35)

And change did come. For years, college enrollment among minoritized populations increased dramatically, approaching parity with their more socially privileged counterparts (National Center for Education Statistics, 2012). What did not improve substantially, however, were these students' experiences and outcomes in college. As more minoritized youth enrolled in college, gaps by race and ethnicity in completion endured and, in some cases, worsened (Ryu, 2009). Today, in an era defined by debates about the post-racial and what some even term a "racially transcendent diversity" (Paradise, 2011), we must ask: What of the experiences and outcomes of minoritized college students? What is the way forward? Diversity initiatives and campus climate assessments are common responses (S. R. Harper \& 
Hurtado, 2007; Iverson, 2012), but what has gone virtually unanalyzed is the relatively nascent turn to an equity orientation in research and practice in higher education. ${ }^{2}$ Below, I provide a brief overview of the rise of diversity and equity orientations, respectively, within higher education.

\section{Seeking Diversity}

Colleges and universities initiated race-conscious programs in the 1960s as one remedy for the historical disadvantage that limited minoritized students' access to higher education (Bloom Jr, 1998; Brest \& Oshige, 1995; Skrentny, 2002). These programs mirrored a larger movement in which civil rights activism resulted in policies that were aimed to increase the inclusion of minoritized populations in the country's social institutions (Allen, Teranishi, Dinwiddie, \& Gonzalez, 2000; S. Harper \& Reskin, 2005). The "special, systematic corrective actions" of these compensatory affirmative action policies relied on race-conscious mechanisms (Allen et al., 2000, p. 5; Bowen \& Bok, 1998; Bowen, Kurzweil, Tobin, \& Pichler, 2005). Unlike the antidiscrimination programs that preceded it, affirmative action aimed to shield members of protected groups from discrimination rather than compensate individuals who had experienced discrimination (S. Harper \& Reskin, 2005). As other populations were recognized as protected groups, attention to diversity rather than to remedies for ongoing discrimination helped to redefine affirmative action efforts (Allen et al., 2000; S. Harper \& Reskin, 2005). The Supreme Court also institutionalized this redefinition. In 1978, Justice Powell, in his opinion in Regents of the University of California v. Bakke (1978), rejected racial set-asides and articulated what came to be known as the "diversity rationale," noting that the educational benefits that accrue to all students in a diverse environment justify the use of race-conscious practices in higher education (S. Harper \& Reskin, 2005; Orfield, Marin, Flores, \& Garces, 2007).

Despite affirmative action efforts in government, industry, military, and education, however, this compensatory approach never became a widely

${ }^{2}$ I attend to diversity and equity frames in this analysis because of their relatively longstanding prevalence within domestic scholarship on higher education, but they are not the only frames that center the issues raised in this analysis. Other frames relevant to this inquiry-equal educational opportunity and equality of (educational) opportunity-are not addressed here because they tend to be employed more consistently at the K-12 level, to apply to subareas within higher education rather than to the field writ large (e.g., in reference to women's access to and participation in higher education), or are no longer common within higher education discourse (see, for example, Coleman, 1968; Meyer, 2016; Rose, 2015; Sewell, 1971). Another frame gaining momentum among higher education practitioners - inclusion-is also related to the present inquiry, however, its relative newness within higher education discourse and scholarship sets it apart from diversity and equity frames, which are currently consistently in-use within higher education scholarship and practice. 
held social agreement. Orfield and colleagues, among others, have traced the well-documented and consistent legal and political attacks on the policy, which have contributed to an "affirmative action crisis" (Orfield et al., 2007; Orfield \& Miller, 1998). The 1990s brought sustained and, in some cases, successful legal challenges to affirmative action (Aguirre \& Martinez, 2003; Tienda, Leicht, Sullivan, Maltese, \& Lloyd, 2003). In what S. Harper and Reskin (2005) refer to as a "turning point for [affirmative action] in higher education," the University of California Regents initiated in 1995 what was to become a series of state-level bans on the use of preferences of any sort in higher education (Garces, 2012; S. Harper \& Reskin, 2005, p. 362). Against this backdrop, the Court upheld the diversity rationale in subsequent decisions, and validated pursuit of a "critical mass" of minoritized students to realize diversity's benefits (Ancheta, 2007). In one sense, affirmative action has survived these challenges even as legal support for race-conscious practices has been chipped away and the defense of affirmative action approaches has taken a race-neutral, though not legally necessary, tack (Cokorinos, 2003; Garces, 2012; Morfin, Perez, Parker, Lynn, \& Arrona, 2006).

In the midst of these negotiations, a range of stakeholders realized thathaving defended affirmative action on moral grounds-they had failed to document the value of increased diversity in higher education (Ibarra, 2001). Hurtado, Milem, Clayton-Pedersen, and Allen (1998) issued a call to educational researchers to "provide evidence of the educational outcomes of diversity in a way that puts the benefits of diversity at the center of the educational enterprise" (p. 280). Researchers took heed, investigating diversity's educational benefits (e.g., Chang, Astin, \& Kim, 2004; Chang, Denson, Saenz, \& Misa, 2006; Gurin, Dey, Hurtado, \& Gurin, 2002) and, more recently, the effects of affirmative action bans on minoritized students and their college experiences (e.g., Cortes, 2010; Dickson, 2006; Hinrichs, 2012; Long, 2007; Tienda et al., 2003). Once a full affirmative action ban- "the feared, catastrophic outcome" - did not come to pass, however, Banks (2007) argued for a new approach, "Rigorous research can now be geared not toward defending what institutions have decided to do, so much as providing guidance as to what they should do" (p. 53). Nevertheless, the turn to diversity may have forestalled this possibility. Scholars argue that the diversity rationale led to increased use and long-term adoption of an "innocuous" diversity discourse in higher education, in part, as a way for college and universities to signal their commitment to an evolving legal environment (S. Harper \& Reskin, 2005, p. 374).

\section{Seeking Equity}

The impetus for the emergence of an equity frame-especially as it relates to race in higher education-is more difficult to identify. Clancy and Goastellec (2007) note equity's rise without identifying its source: "Increasingly it 
is recognised that it is necessary to go beyond formal equality of rights and take account of differences in the opportunity structure" (p. 139). I offer here one potential line of development of the equity frame: a relative handful of scholars maintained focus on continuing disparities faced by minoritized populations, the existence of which has systemic equity implications (see Astin \& Oseguera, 2004; Musil, 1996; Musil et al., 1999; Tierney, 1997). These scholars, like Anderson (2005), believed that "common sense endorsements of diversity and affirmative action does [sic] little in the way of guaranteeing greater access for racialized students" (p. 417). In fact, many concerned with equity felt as sharp blows Court decisions that continued to shift away from compensatory programs. One such scholar, D. Bell, wrote following the Grutter v. Bollinger (2003) decision:

These are difficult times for those working for racial equity, and there seemed reason for declaring victory after a years-long litigation that many ... predicted would result in the invalidation of any use of race in the admissions process. I fear ... that further events ... will render this latest civil rights victory ... hard to distinguish from defeat. (D. Bell, 2003, p. 1622)

Despite some progress, equity-focused scholars argued, inequities persisted in social life and in higher education and these were worthy of redress for their own sake (Allen et al., 2000; Teranishi, Allen, \& Solorzano, 2004). Rather than shoring up the diversity rationale, these scholars attended to different ideals - often those focused on an "American cultural ethos" and the role of education in a democracy (Allen, 2005, p. 18; Tierney, 1997). For example, Allen et al. (2000) asked if the nation would "live up to the inspirational creed of the American Dream by offering freedom, opportunity, and equality to all, or will it continue to deny these ideals and by so doing lay the foundation for the destruction of yet another great civilization" (p. 10). ${ }^{3}$

Equity-focused efforts and rationales appeared in response to widespread discrimination faced by minoritized populations and what many saw as the reversal of civil rights era gains (Allen, 2005; D. Bell, 1980; Yosso, Parker, Solórzano, \& Lynn, 2004). From this vantage point, scholars were concerned about the reproduction of an inequality of opportunity and challenged the unequal power structures they saw as the root of many of the challenges and disparities that minoritized students continued to face in college (Clancy \& Goastellec, 2007; S. R. Harper, Patton, \& Wooden, 2009; Yosso et al., 2004).

${ }^{3}$ Interest in equity can be also be linked to concerns about disparities and demography. Scholars have argued that as the numbers of minoritized and low-income individuals increases, ongoing disparities for such a large portion of the population will pose a significant equity challenge (Anderson, 2012; L. I. Brown, 2004). 


\section{Research Design}

This article offers analysis of the differential use of diversity and equity frames in higher education scholarship and discusses the implications of their use for racial justice in higher education. A critical turn grounds this study and emphasizes connections among how "we" talk, think, and act in regard to racial justice. Lynch (2006) offers that critical interpretation involves questioning the "assumptions underlying material that is already interpreted" (p. 293). Other critical scholars offer essential questions to guide scholarly and institutional practice (D. Gillborn, 2005; Taylor, 1997): In whose interests? Who wins? Who loses? The primary query for this critical review asks how diversity and equity frames may differentially influence scholars' and practitioners' efforts to recognize, interpret, and respond to racial inequities. Scholarship is a particularly important area for such an analysis because it both represents and informs institutional practice and shapes subsequent inquiry (Kincheloe \& McLaren, 2011).

This critical examination of diversity and equity discourse-the unities and disjunctures between the two-in higher education scholarship is guided by the following research questions:

- What is the most influential literature related to diversity and equity in higher education scholarship, as measured by number of citations?

- How are "diversity" and "equity" employed in this influential higher education literature?

- What concerns related to race are centered in this influential literature?

- In what ways does this influential literature attend to racial justice in higher education?

\section{Data Sources}

Search procedure. The literature reviewed for this analysis was identified in two stages using three multidisciplinary academic databases that provide citation counts (i.e., Google Scholar, ProQuest Research Library, Web of Science). Because the focus of this review is on influential published scholarship, I included peer-reviewed journal articles, books, and book chapters (Turner, González, \& Wood, 2011). First, I employed two key-word searches to identify references whose titles contained "diversity and "higher education" or "equity and 'higher education,", which yielded 1,440 and 1,230 references, respectively. Second, given my interest in the ways in which concerns about race, ethnicity, and minoritized populations emerged, I aimed to determine whether diversity and equity frames are used differently in references that specifically mention race and/or ethnicity or that focus on minoritized groups in higher education. To do so, I generated two additional sets of literature for "diversity and 'higher education' and race" and "equity and 'higher education' and race," which yielded 41 and 34 references, respectively. 
In addition to increasing the feasibility of a wide analysis of literature, a titles-only approach has practical value because it represents "the first and most obvious means" through which others would identify the focus of a particular reference (Buhrke, Ben-Ezra, Hurley, \& Ruprecht, 1992; Townsend, Donaldson, \& Wilson, 2009, p. 710). Other scholars have used article titles to conduct comparable analyses of higher education literature (see Buhrke et al., 1992; Creamer, 1994; Donaldson \& Townsend, 2007). That said, the approach does introduce a limitation. It overlooks references that are centrally focused on diversity or equity but that do not have titles that reflect this emphasis (Donaldson \& Townsend, 2007). Nevertheless, this selective review can serve as a proof of concept that highlights the use to which scholars put diversity and equity frames in this subset of higher education scholarship. Further research would be needed to identify the extent to which this is an accurate representation of the broader field.

Selection criteria. I further reduced the population of references using three criteria: 1) publication date, 2) content focus, and 3) citation frequency. First, the final set of references analyzed was published between 2000 and 2015. While this does exclude older pieces that may have been influential, this time frame usefully limits the review to references that are important within contemporary scholarship. In addition, the emphasis in this analysis on topcited references, as discussed below, suggests that ending the review in 2015 does not exclude more recently published references because these have not yet had the opportunity to reach the level of citation that would have made them eligible for this analysis. Second, given the focus on higher education broadly, I attended to references that focus on the field of higher education, generally, rather than on specific disciplines or institutional sub-settings (e.g., business, women's studies, law, special education). I also excluded workplace research, leadership and management studies, scholarship on pedagogy, and references that employ "diversity" to examine higher education institutions themselves or the organization of the higher education system - that is, those that focus on institutional or structural diversity within higher education. However, I did include legal studies that consist of critical analysis of the state of diversity or equity discourse in higher education because analysis of what is being done or can be done with equity or diversity frames is central to this review. I included international or comparative studies that explicitly discuss or are relevant to the U.S. context.

Finally, many analyses of content and discourse in education scholarship center leading or core journals (e.g., Banning, Ahuna, \& Hughes, 2000; Creamer, 1994; Donaldson \& Townsend, 2007; Kuh \& Bursky, 1980). Rather than attempting to encapsulate a field of scholarship, as shaped by research journals (Townsend et al., 2009), I aimed to document the contours of a particular conversation about equity and diversity in higher education. 
Therefore, my selection criteria were weighted toward those texts that appear to play a significant role in that conversation. As Lynch (2006) argues, "Dominant interpretations have enormous influence, because they shape not only the way scholars ... see a particular set of issues, but also what kinds of questions about these are considered legitimate for scholars to ask" (p. 294). Thus, taking a lead from Halverson and colleagues, I drew my attention to dominant interpretations in literature with "significant currency, resonance, timeliness, and influence" - that is, references that have gained the most attention as measured by frequency of subsequent citation (Halverson, Graham, Spring, \& Drysdale, 2012, p. 20; Halverson, Graham, Spring, Drysdale, \& Henrie, 2014). ${ }^{4}$

On the whole, the literature identified in the searches that included race were cited less frequently than those that did not include race. This was true of the literature subsets for both diversity and equity scholarship. Thus, to maintain focus on the top-cited literature and to expand the amount of literature that could be investigated in the "diversity and 'higher education' and race" and "equity and "higher education and race" literature sets, I employed a threshold of 25 citations for these subsets. As a result, in the searches that did not include race, reviewed references were cited a minimum of 50 times. In the searches that did include race, references were cited a minimum of 25 times. Based on these guiding parameters, I reduced the population of references to those that focally address diversity or equity in higher education, were published between 2000 and 2015, and were cited a minimum of 50 or 25 times, depending on the subset.

This left a final sample of 30 references that formed the core of this critical analysis:

- Diversity, higher education: 8 references, cited at least 50 times

- Diversity, race, higher education: 8 references, cited at least 25 times

- Equity, higher education: 8 references, cited at least 50 times

- Equity, race, higher education: 6 references, cited at least 25 times

By crafting these inclusion parameters, I do not mean to suggest that this expanded handful of articles represents the full extent of debate and research

\footnotetext{
${ }^{4}$ In addition, I extrapolate here on Delgado's $(1984,1992)$ notion of "imperial scholarship" to center texts that are prevalent in higher education scholarship. Delgado (1984) coined the term to refer to the work of a small handful of White, male scholars who dominated legal scholarship on civil rights, measured — in part—by citation frequency. While Delgado investigated the ways in which this group of writers was able to keep minoritized scholars out of a field related to race and the law, imperial scholarship is applicable here, more generally, in terms of the scholarship that appears to be most prominent in the field-with no particular gatekeeping function implied.
} 
regarding diversity and equity in higher education. I do, however, mean to query references whose content is sharply focused on these issues and, based on the extent to which other scholars engage their ideas, most pervade discussion in these critical areas.

\section{Analytic Procedures}

To review the collected scholarship, I created a coding scheme to identify characteristics most relevant to this study and to analyze patterns and themes related to the use of equity and diversity frames in this set of higher education scholarship (Donaldson \& Townsend, 2007; Mars \& Rios-Aguilar, 2010). The coding scheme included the following five elements:

- Topic: Content focus of each text;

- Purpose: Author(s)' stated objectives;

- Stance: Author(s)' motivation based on content or the conclusions drawn from analyses;

- Framing: Use and content of definition of diversity or equity employed; and

- Race: Attention to race and/or particular racially minoritized population(s).

After this initial round of coding, I conducted inductive thematic analysis to further deconstruct the articles' content (Boyatzis, 1998; Charmaz, 2014). This thematic analysis allowed for closer investigation of each article in terms of its content, relevance and meaning given the goals of the larger inquiry (Saldaña, 2009). In addition, this inductive approach helped to ensure that the resultant themes were fully data-driven and emic - that is reflective of the concerns articulated by the articles' author(s) (Denzin \& Lincoln, 2008).

Guided by the inquiry's research questions and the emergent patterns in the thematic analysis, I then conducted focused coding to identify themes related to diversity, equity, and racial justice as well as points of similarity and divergence within these themes within each article subset (Charmaz, 2014; Fereday \& Muir-Cochrane, 2006; Saldaña, 2009). This resulted in the cluster of themes reported in the findings section below. For example, I identified the following themes in the eight articles in the "diversity and higher education" subset: affirmative action, supporting diversity, and diversity discourse. Further, the four articles under the affirmative action theme were further coded to reflect the articles' emphases within this theme-specifically on various aspects of the educational benefits of diversity: skill development, preparation for a multicultural society, workforce competencies, and inhibited by merit. These themes, along with review of the full text, enabled me to investigate each reference's deployment of diversity and equity, and how each relates to the larger project of racial justice in higher education. 


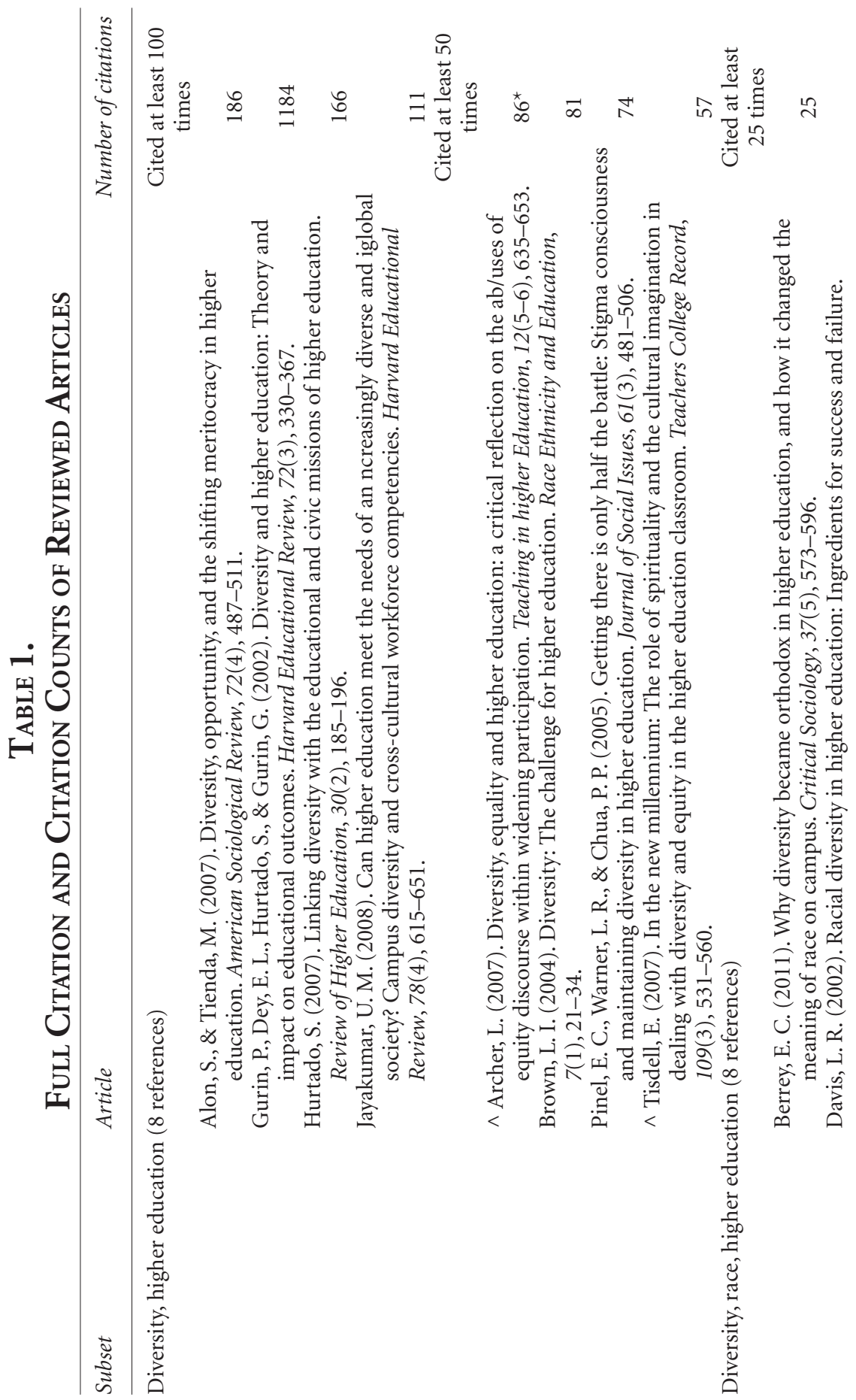




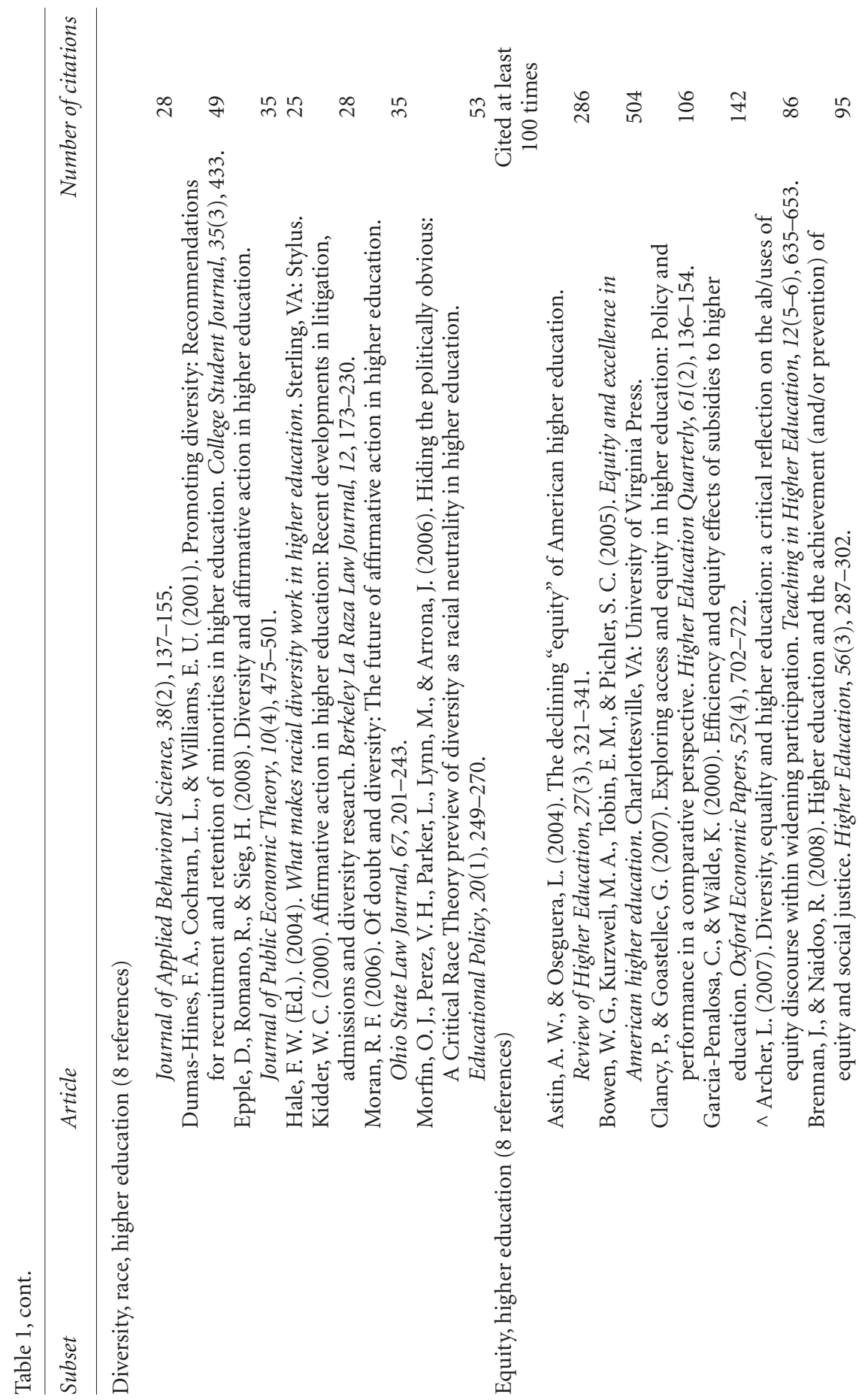




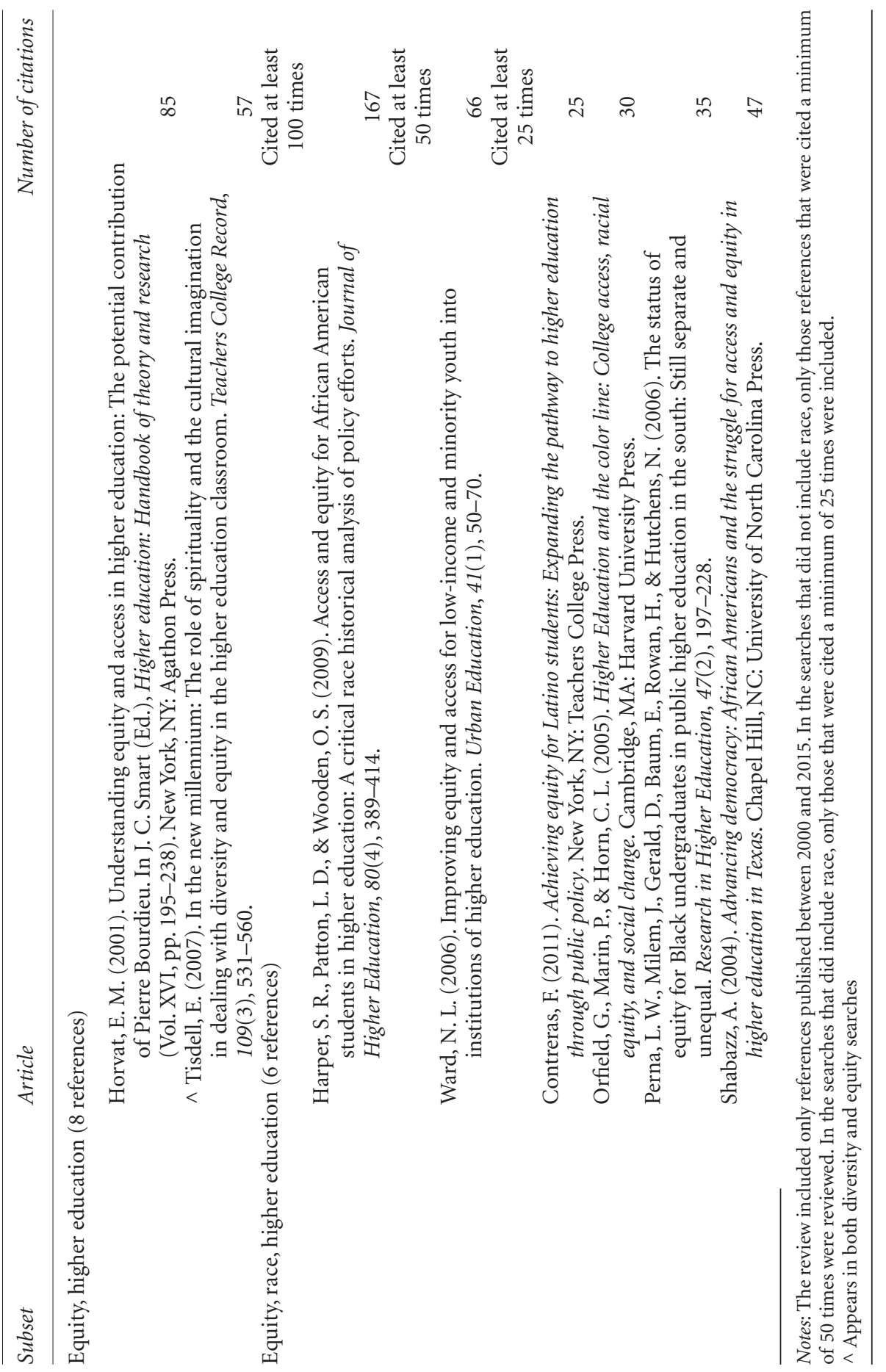




\section{FINDINGS}

\section{Diversity and Higher Education}

Eight articles in this review are centrally concerned with diversity and higher education. Four of these focus on affirmative action with three highlighting the benefits that can emerge from diverse learning environments. Three advocate for institutional approaches that support diversity. One discusses how the use of diversity rhetoric in higher education policy maintains the visibility of the issue while hiding its complexities. (See Table 2 for an overview of themes covered in reviewed articles.)

Educational benefits of diversity. The most widely cited articles (i.e., more than 100 times) that focus on diversity and higher education are concerned with affirmative action, particularly the use of race-conscious admissions practices. Three of the four articles address the educational benefits of diverse learning environments-academic, civic, and economic gains that, the authors argue, are needed in a democracy, in diverse workplaces, and in a global society.

By far the most “influential," Gurin, Dey, Hurtado and Gurin (2002)—cited more than 1,000 times - argue that a diverse learning environment is beneficial to all students and helps higher education institutions meet their civic and learning missions. Their analyses demonstrate that students' classroom-based and informal interactions with diversity on campus are positively related to academic skills and intellectual and civic engagement, among others deemed central to participation in a diverse democracy. Hurtado (2007) — a co-author of Gurin et al. (2002) — asserts that pursuit of these educational benefits is part of a transformation effort that would make diversity concerns central to higher education's work of "prepar[ing] the next generation of citizens for a multicultural society” (p. 186). Jayakumar's (2008) analysis identifies relationships between diverse learning environments and "cross-cultural workforce competencies" that enhance White students' "ability to adapt to different perspectives and cultures" (p. 636). Together, these articles emphasize diversity's benefit to "all students" or, more specifically, to White students, which indirectly counters the notion that diversity efforts are enacted only on behalf of minoritized populations. In the final article, Alon and Tienda (2007) note that a narrowing definition of merit in college admissions (i.e., test scores, resistance to race-conscious practices) inhibits equal educational opportunity for minoritized populations.

Supporting diversity. In the next set of three articles, authors emphasize the changes needed to support diversity in higher education. L. I. Brown (2004) underscores the need for more meaningful action, particularly given the widespread pronouncement of institutional commitments to diversity. Pinel, Warner, and Chua (2005) and Tisdell (2007) advocate for efforts to, respectively, decrease minoritized students' consciousness of their stereo- 


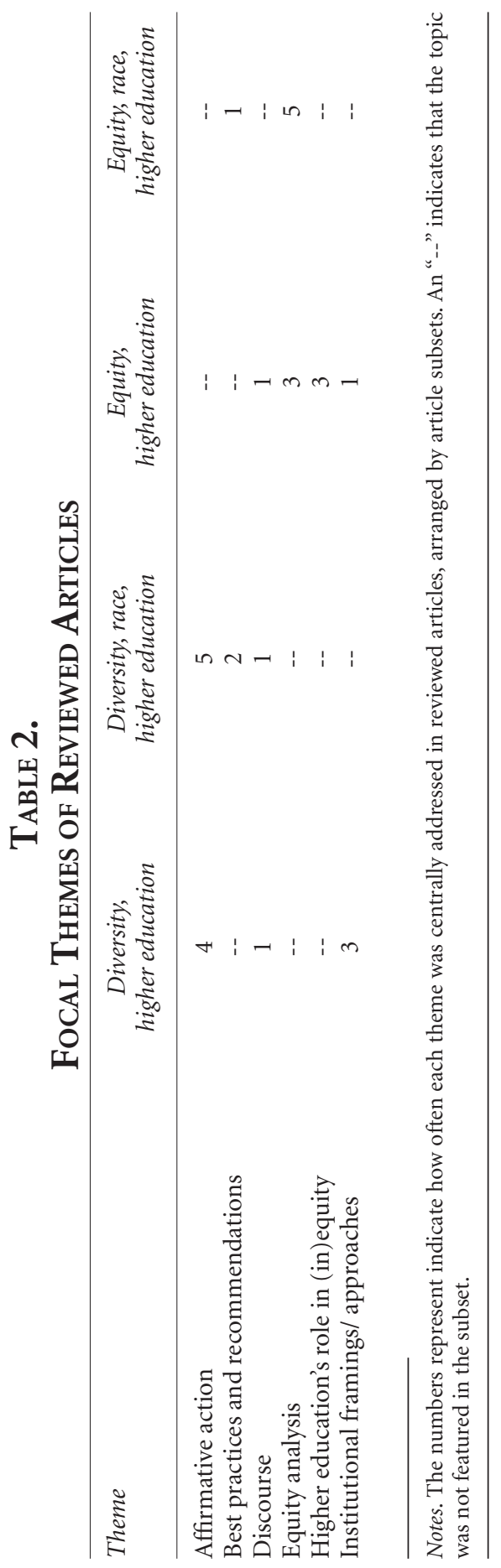


typed status and to incorporate spirituality into the classroom as one link to students' cultural identities. Authors also highlight the role of diversity not as a divisive force but as one that can contribute to unity and even a "sense of oneness" (L. I. Brown, 2004, p. 29).

Diversity discourse. Archer (2007), who writes from the United Kingdom but whose analysis is relevant broadly, is the only author to explore diversity discourse. Archer charges that higher education policy presents diversity as:

an unquestionable proposition ... [that] operates as a powerful justificatory discourse within policy ... that signifies "good for everyone" rather than just "good for some" ... [and] as a moral discourse-and the power of moral discourses lies in their capacity to silence and render alternative accounts "unsayable." (p. 648)

This discourse, Archer continues, separates social difference from patterns of social inequity, rendering this inequity invisible while making some bodies more visible with the concomitant need to manage diversity. Archer (2007) concludes by urging consumers of higher education policy-that is, all of us - to be wary of diversity's work and what it may silence.

Diversity, higher education, race. Among the eight most widely cited articles - cited a minimum of 25 times - that connect race to diversity in higher education, a preoccupation with affirmative action is evident. Five articles engage the affirmative action debate with three examining law and/ or practices on campuses or in higher education generally, and one reframing a key concept in order to make affirmative action more palatable. The fifth draws most centrally on critical race theory to examine institutional responses to the diversity rationale. Two of the other articles present diversity success stories that showcase or propose best practices. Again, only one article explores diversity discourse, addressing how and why higher education has embraced diversity rhetoric so roundly.

Affirmative action law and practices. Based on interviews with representatives from 16 institutions that more or less successfully leveraged affirmative action practices to increase racial diversity, Davis (2002) offers a potential best practice: recruit progressive-thinking students, faculty, staff, and administrators who are committed to racial diversity. Others imply that the orientation toward how might be premature at a time when the legality of if is still being debated. While Kidder (2000) offers a unique interpretation that the much-touted diversity rationale merely reflects the personal opinions - rather than validated legal opinion - of select Supreme Court justices, Epple, Romano, and Sieg (2008) approximate race-blind and race-sighted admission models. Their results indicate that use of race-blind approaches would detrimentally affect racial diversity and financial aid for minoritized students at selective colleges. 
Reframing "critical mass." Wary of an affirmative action ban, Moran (2006) offers a new conceptual framework meant to be more aspirational than the diversity rationale, which the author frames as a legitimate, if politically and practically ambiguous, justification for affirmative action. Moran's "synthetic approach" emphasizes the need for:

a critical mass of students of color [that] can learn unburdened by the stigma and isolation of being token presences on campus ... Because this critical mass of underrepresented students can become full members of the campus community, all students enjoy the chance to share thoughts and experiences regardless of race or ethnicity. (p. 239)

Moran (2006) imagines this framework will enliven discourse by linking it to fundamental democratic values (e.g., membership, participation, liberty) and will remake the normative commitment to "corrective justice" that Brown v. Board of Education of Topeka (1954) captured.

Institutional preferences for race-neutrality. Morfin et al. (2006) charge that even within what is currently legally permissible, higher education institutions are largely making only symbolic attempts at change. While the authors lament the loss of the legal use of race as a remedial and justiceoriented strategy, they argue that a legally unnecessary preference for raceneutrality pervades higher education and inhibits institutions from using race-conscious practices to generate racially diverse student bodies. Morfin et al. (2006) conclude that the diversity rationale ultimately offers a "loophole" that allows institutions to retreat from race.

Diversity success stories. Dumas-Hines, Cochran, and Williams (2001) offer a mission-focused strategy that starts with the creation of a cultural diversity statement for the university and moves through analysis of cultural diversity on campus, research on best practices, and implementation of a comprehensive recruitment and retention plan. Following a similar howto inspiration, Hale (2004) presents the stories and reflections of diversity leaders whose efforts have made a positive impact and whose experience can inform inclusion efforts elsewhere.

Diversity discourse. Berrey (2011) contextualizes a retreat from race in higher education, situating it as part of a larger discursive move in toward a "racial orthodoxy [that] treats race as one of many valued cultural identities" (p. 574). The diversity of this racial orthodoxy, Berrey argues, is both color-conscious and racially ambiguous, allowing institutions to emphasize instrumental and interactional benefits of diversity while conflating racial difference with cultural difference. Berrey contends that "rather than prioritizing only the needs of racial minority students, diversity discourse and initiatives often incorporate, represent, and even cater to [W] hite students" (p. 574). In fact, this racial orthodoxy need not include race at all, which 
creates a way for institutions to advertise diversity commitments to their reputational advantage without making racial commitments that may be untenable in the current political climate.

\section{Equity and Higher Education}

Of the eight references that focus on equity and higher education, three center the relationship between the two and discuss the contribution of higher education to increasing or decreasing social equity. Three others offer analyses that reveal the current state of equity in higher education. One article is devoted to each of the following: how institutions can create community amidst diversity through intentional classroom practices, and the role of discourse in shaping how equity is understood in higher education contexts.

Higher education and social equity. By far the most widely cited, Bowen et al. (2005) — cited more than 500 times_-inadvertently set the tone for this subset of articles. The authors note that progress toward equity in higher education has not proceeded uninterruptedly toward increased inclusion; it "is more like observing someone taking one step forward and two steps backward than it is like watching a steady sequence of forward-moving giant steps" (p. 14). In fact, the authors propose that the forces pushing against increased equity have been evident and formidable for decades. According to the authors, the resistance that countered the social welfare goals that President Harry S. Truman's Commission on Higher Education codified in the mid-twentieth century is still alive today in the form of "individuals who dismissed such altruistic rhetoric as misguided and whose defiance and self-righteousness mocked the very notion of equal opportunity" (Bowen et al., 2005, p. 35). Brennan and Naidoo (2008) also explore the connection between social forces and institutional action, framing it as an import-export relationship. While concerns for social justice and equity move in both directions, the authors insist that attention must be paid to the export aspect by asking, "What does higher education do for the achievement of equity and social justice across the rest of society?" (p. 288).

Relatedly, Horvat (2001) argues that structural inequities within and influenced by higher education are left under- or un-theorized because little research investigates the ways in which "the system itself perpetuates the circumstances that help to create these entrenched race- and class-based patterns of access and attainment" (p. 195). In response, Horvat offers and applies a critical theoretical framework that can shift researchers' attention away from examinations of individual characteristics to analyses that make visible institutions' role in perpetuating — and, in some cases, hiding — structural inequities that affect minoritized students' outcomes. As an example, Horvat's analyses demonstrate how and why two Black girls' race and class resources are reinterpreted as the two similarly situated young women enter new social fields of power in the transition to college, resulting in vastly different college experiences. 
Equity analyses. Underscoring the need for additional inquiry, Clancy and Goastellec (2007) are concerned with understanding the ways in which higher education can positively affect equity. Other authors highlight two enduring equity concerns in higher education: intensifying gaps in college access by socioeconomic status (Astin \& Oseguera, 2004) and ongoing tension between narrowing and expanding notions of merit and their effect on college access for minoritized students (Astin \& Oseguera, 2004; Clancy \& Goastellec, 2007). For example, Garcia-Penalosa and Wälde (2000) model the relationship between higher education financing and equity. They find that current funding models inhibit opportunity because they do not mitigate the risk of uncertainty that keeps some students from pursuing college careers.

Classroom practices. Also addressed above in "Diversity and Higher Education," Tisdell (2007) emphasizes the role of spirituality and cultural imagination-as employed in the college classroom through symbols, music, rituals, images, poetry, and art-in helping students' meaning-making processes related to equity in higher education and in society. These approaches touch on more spiritual elements, the author argues, which creates a third approach that can integrate with the intellectual and critical elements of college teaching to enhance student learning about and engagement with equity issues.

Equity discourse. Archer (2007), also cited above in "Diversity and Higher Education," argues that pursuit of equity in higher education has been hamstrung by equality and diversity discourses that emphasize the individual over the structural. This muddies, Archer argues, problem definition and pursuit of solutions given that, for example, "the causes of unequal [college] participation are divorced from the structures and practices that create and frame participation" (2007, p. 643). As a remedy, Archer advocates for untwining the common sense connection between diversity and equality to aid the development of more equitable practices.

Equity, higher education, race. The majority of the six top-cited articles that engage equity, higher education, and race present analyses that summarize the state of equity for minoritized students. Five of the articles indicate that despite pockets of progress, equity is largely on the decline for minoritized students. The sixth introduces a promising program.

Declining equity. S. R. Harper et al. (2009) — cited more than 120 timesanalyze the relationship between higher education policy and equity for Black students. Drawing on critical race theory, they find a fits-and-starts approach in which gains have been undermined, resulting in stilted progress that can be attributed to interest convergence in policymaking. D. Bell (1980) introduced the concept of "interest convergence" to argue that Whites support increased equity for minoritized populations only in circumstances in which they, too, stand to benefit or when their interests are not threatened. 
Several other articles present the kind of structural analyses that S. R. Harper et al. (2009) prescribe for generating productive equity policies. Shabazz's (2004) historical case study of desegregation and Black liberation efforts in Texas acts as a snapshot of the larger trends identified in Perna et al.'s (2006) analysis. Perna et al.'s Academic Equity Index reveals that despite moments of progress - in some outcomes, in some states, in some periods, for a period of time-Black students in the south face substantial inequities. Based on case studies that reveal a link between policy and declining equity for Latino college students, Contreras (2011) also advocates for an equity index to situate students' success and to evaluate parity across groups. Orfield, Marin, and Horn (2005) acknowledge that their analyses "present a dominant picture of institutions quietly implementing policies that will almost certainly increase social and economic stratification" (p. 8). As a remedy, the authors suggest that their "educational scrutiny" framework can help institutions can develop, articulate, and align diversity-focused missions and practices that provide accountability for racial justice without relying on a weakening affirmative action.

Promising program. Ward (2006) introduces the federally funded GEAR UP (Gaining Early Awareness and Readiness for Undergraduate Programs) as a promising policy intervention. GEAR UP is a state-based, college access program for low-income and minority seventh graders that extends into college; incorporates school, community, and university partnerships; influences district-wide policy; engages parents; and encourages professional development and training for public school educators. Despite its strengths, Ward concedes that GEAR UP-even with the changes this comprehensive approach spurred-had not been formally evaluated and did not account for some of the school-based restructuring, monitoring, and institutionalization needed to support system-level change.

\section{Discussion}

This analysis offers insight into the relative efficacy of orientations toward diversity or equity, as employed in influential higher education research, to generate opportunities for creative and critical response to racial inequity. Findings suggest that diversity has become an appealing pursuit, in part because its vagueness implies a tolerance for some without making a commitment to all (Ahmed, 2012; Berrey, 2005). Conversely, equity offers an opportunity to shift the conversation back toward educational opportunity for minoritized college students and to push for their full inclusion in higher education contexts. Below, after reviewing what "diversity" and "equity" do in this top-cited higher education literature, I advocate for an emphasis on equity that centers institutional responsibility and action in addressing racial inequities in higher education. 


\section{What Diversity Does: Less Promoting than Defending and Promising}

Based on this review, it is clear that "diversity" is locked in an affirmative action bind that is linked to the diversity rationale advanced in Regents of the University of California v. Bakke (1978). Ten of the eighteen most widely cited references take on affirmative action, most in an effort to shore up the legitimacy of race-conscious admission practices by highlighting the educational benefits of diversity for all students. This affirmative action bind is restrictive for at least two reasons. First, the stance taken in these references is largely defensive. Affirmative action is under attack, and only one legal justification for it remains and even that is continually in jeopardy (see Fisher v. University of Texas at Austin, 2009, 2011, 2013, 2016). Hurtado (2007) reframes the educational benefits argument as a larger transformational effort to help higher education meet its civic and academic missions, and notes that critics charge that attending to legal arguments has shifted attention away from social justice advocacy. However, Hurtado's assertion that concern about diversity's educational benefits is not primarily motivated by their centrality to legal arguments belies the affirmative action preoccupation in the literature. And a rhetorical framework that cannot explicitly advocate for compensatory action to ameliorate racialized inequities offers no compelling rejoinder. Even D. Bell (1976), a well-known legal scholar, asserted that the pursuit of racial equity through the law, though a necessary endeavor, is inherently limited and cannot be counted on as a primary source of protection for minoritized populations. Given the lack of urgency about racial inequities within affirmative action debates, Hurtado argues, real opportunity for change lies in the educational benefits of diversity research:

The goal of this emerging body of work is the production of citizens for a multicultural society that can result in leadership with greater social awareness and the complex thinking skills to alleviate social problems related to the complexities of inequality. The end goal is the improvement of education for students from different racial, economic, and religious communities who must work together to achieve a vision of the pluralistic democracy we aspire to become [emphasis added]. (2007, p. 193)

An emphasis on the learning outcomes related to diversity, even if they do include critical thinking and an expanded worldview, cannot address largescale causes of educational inequities.

A second concern with the affirmative action orientation within the diversity literature is the reality that the policy is relevant only for a small number of students who attend or seek to attend a relatively small number of "elite" institutions. This is demonstrated by the recognizable names linked to key affirmative action cases: University of Michigan, University of Texas-Austin, University of California-Davis. Access to this set of institu- 
tions is inevitably limited but, regardless, most students-particularly most minoritized students-access higher education through considerably lower status colleges and universities (U.S. Department of Education, n.d.). The disproportionate effort expended on institutions attended by relatively few minoritized students misrepresents the most prevalent racial equity concerns in higher education, not the least of which is the stratification that relegates minoritized students to institutions that have fewer resources and where they may be less likely to be successful (Astin \& Oseguera, 2004; Gansemer-Topf \& Schuh, 2006; Karen, 2002; Melguizo, 2008).

This critical review of literature also reveals that the orientation toward diversity often entails a retreat from race (Berrey, 2011; Morfin et al., 2006). Contemporary concern for diversity requires an orientation toward "all students," which can be translated to "White students, too" or, simply, "for White students" (Yosso et al., 2004). Parallel to this retreat is decreased emphasis on institutional intervention on behalf of minoritized students and increased prevalence of practices that may benefit dominant groups and obscure structural realities that are linked to racial inequities (Jayakumar, 2008; Renner \& Moore, 2004). As Berrey (2011) reminds:

the push for diversity entails, at once, a focus on race and a shift away from race ... In contrast to the logic of remedying racial disadvantage, which relies on a structural explanation of racial exclusion, the logic of diversity provides a cultural explanation of inclusion. Rather than emphasizing the imperative of social justice, diversity discourse and many diversity programs stress the instrumental benefits of racial identity and of interpersonal interaction along racial and other lines. (p. 577)

This retreat from race has been aided by a rhetorical transformation in which diversity no longer explicitly signals a concern for race and ethnicity. Instead, the emphasis is on cultural differences and helping students negotiate the range of viewpoints and experiences embodied by a diverse group of students. Race may be included, but certainly need not be-a flexibility that allows the roots and structures of systemic inequities to fade into the background (Berrey, 2011). Andersen (2001) challenges this desire for "diversity without oppression" in which "people can simultaneously recognize diversity, but not oppression; deny difference and appreciate diversity; [are] conscious of racial differences, but not conscious of continuing racial injustice" (p. 199). This incoherent simultaneity inhibits diversity's potential as a lever for serious social change. Diversity elides power differentials among cultural groups, and thus lacks an emphasis on the cultural and structural realities that undergird social inequity (Blackmore, 2006). Here, inclusion relies on a "politics of presence" through which representation in a context of "mosaic multiculturalism" is held as the epitome of positive change rather 
than a theory of social justice that could spur transformational institutional change (Benhabib, 2000; Blackmore, 2006).

Further, this cultural difference approach emphasizes the instrumental benefits of diverse learning environments (see Hurtado, 2007; Jayakumar, 2008). While true that students can be enriched through interaction with diverse others in intentionally structured contexts and conditions (Garces \& Jayakumar, 2014; Hess, 2009), ${ }^{5}$ a narrow focus on instrumentality can contribute to a commodification of diversity in several ways. First, diversity becomes something to be consumed and, perhaps, enjoyed. While diversity may be "good for everyone" (Archer, 2007, p. 648), the imagined "I" is meant to value it because it is good for me. One's commitment to diversity, then, extends only so far as the personal value one sees in it. In this design, the task of diversity advocates is to convince dominant "others" that diversity is valuable to them, which places the importance of diversity in what it creates for dominant others rather than for the minoritized others who appear to make a space diverse. Once diversity centers on consumption value-that is, me and my personal benefit - there is no legitimate foothold for arguments based on the benefit to minoritized populations, likely leaving the norms and practices of the institutions where this diversity is to be housed unchanged (Prasad \& Mills, 1997).

Second, the pursuit of diversity in relatively un-diverse settings can lead to the commodification - or commoditization-of racialized cultural goods. Anderson (2005) writes that one of the achievements of diversity discourse has been a diversification of the curriculum — an achievement that leverages a discourse of difference without attending to the politics of inclusion. Due to limited access and constrained outcomes for minoritized students in higher education, this diversified curriculum largely exists in spaces from which minoritized students are relatively absent. By allowing "students 'without color' to exchange ideas, redefine and/or reinterpret texts that contest and give voice to racialized identities, as well as chronicle the experiences of communities of color," many diversity-related efforts substitute the social value of discourses of diversity for non-minoritized students with an enacted commitment to educational opportunity for minoritized students (Anderson, 2005, p. 411).

Finally, this commodity orientation to diversity makes the presence of cultural diversity an asset that institutions can advertise and leverage to gain competitive advantage. That is, not as a social goal that is subject to critique,

${ }^{5}$ Garces and Jayakumar (2014) argue that more than critical mass — which centers primarily on numerical representation - is required for higher education institutions to realize the educational benefits of diversity. The authors offer "dynamic diversity," which rather than critical mass, requires that "contextual factors of the learning environment set the stage for and facilitate productive interactions and exchanges across racial lines" (p. 117). 
but as a tool for institutional advancement, a "condition to be prized and nurtured" not merely tolerated (R. H. Brown, 2002, pp. 1081-1082). The link between the appearance of diversity and institutional image-making creates a representational value in diversity or even in the mere appearance of diversity. If one accepts that there is an instrumental value-educational, civic, or economic - in individuals interacting in diverse spaces, institutions that purport to provide such spaces offer access to a relatively scarce good (R. H. Brown, 2002). This makes of diversity a product that student consumers just must have and institutions must provide, such that diversity marketing has become a lucrative endeavor - that is, marketing not to minoritized populations in search of inclusive environments but to non-minoritized populations in pursuit of valuable, yet elusive, diversity opportunities (Prasad \& Mills, 1997). This marketing also serves to sanitize diversity, presenting wholesome images of assimilated difference. For example, Swan (2010) critiques the "photograph of the "mosaic" — shiny, happy (diverse) people holding hands-because it "visually represents racial difference within a sameness grid ... [that] obscures unequal power relations and attempts to defuse political antagonism from minoritized groups, and placate the imagined [W] hite viewer" (p. 78). With antagonisms defused, the minoritized other becomes digestible, helping to confirm for the White viewer that s/he can consume the diversity being offered-saying, Diversity is great but if you're afraid of being uncomfortable, don't worry, we all fit, we're all the same. We may appear to be different but really we're the same as you. These images ironically promise a diversity that - thanks to challenges to race-conscious practices and narrow notions of merit-is continually under attack and available only in certain geographies of the higher education landscape.

Based on this analysis, I conclude that diversity and its current use in topcited higher education research is an ineffective avenue through which to pursue meaningful change toward racial equity. Renner and Moore (2004) argue more sharply that the emphasis on diversity has impaired racial equity because it has been a diversionary tactic that maintains the status quo, writing, "We cannot go from desegregation to equity through diversity. We can get from desegregation to diversity through equity" (p. 237). While scholars have advocated for more interactional or transformative framings of diversity (see Chang, 2002; Garces \& Jayakumar, 2014; Pursley, 2003), the concept nevertheless is often taken as a static representation that results merely from who is in the room (Allen et al., 2000). It merely is. It is not at work; it is not doing. Given the narrow focus on this idealized room, at best what is required is that the group of gathered individuals merely get along-the world outside need not exist, need not trouble us. 


\section{What Equity Does: Setting a Standard, Asking Questions, Expecting Action}

While I am underwhelmed about the potential of a diversity frame to generate scholarship and practice that aim to eradicate racial inequities in higher education, I am relatively, and reluctantly, cautiously optimistic about what equity can do for several reasons - its presumption of an absolute standard and its embedded orientation toward inquiry and action.

First, equity is normed. It is set against a standard-the definition of which may fluctuate by context but - that entails recognition of disparities and their mechanisms. Equity invariably frames the query relative to groups' progress toward other values - for example, educational opportunity, access to higher education, success outcomes (Gillborn \& Youdell, 2000). Further, an equity orientation moves away from the equal treatment of all groups to emphasize "access and removal of barriers for historically disadvantaged groups" (Ng, 2003, p. 19). Equity, thus, has an external referent that is not the sole creation of higher education institutions and that allows institutions less absolute discretion in local framings. Instead, local practices and outcomes, to some extent, must reflect and affect external equity concerns (Valli, Cooper, \& Frankes, 1997). In addition, the definition or metrics of interest are not necessarily predetermined; that is, pursuit of equity need not be enacted on behalf of affected parties but, rather, can be constructed with them (Zine, 2001). Equity entails the opportunity to establish shared definitions of success that can link representation with inclusion and participation. In this way, equity is not up for debate. It is a value to get behind. This analysis reveals that equity is assumed to be always already preferred, which is evidenced by authors' lack of preoccupation with convincing readers that equity is a legitimate value.

Second, equity emphasizes the need for inquiry. The articles in this review reveal a shared concern for assessing, documenting, and making visible the relationship between higher education and educational inequity, especially for minoritized students. In particular, critical theory offers productive tools with which to examine power and privilege in higher education, and the ways in which institutional norms - in specific institutions or higher education broadly-help to (re)create these power relations. For example, S. R. Harper et al. (2009) offer a policy analysis that leverages critical race theory to explore how policy can reproduce inequity, and they conclude by underscoring the necessity of efforts to better understand educational equity, and its requisites, for minoritized populations. Pasque, Carducci, Kuntz, and Gildersleeve (2012), too, offer an inquiry- and action-driven characterization of what equity requires of higher education scholars. They write:

equity, as a concept, provides a unifying political goal for scholars interested in fostering social justice in, by, through, and for the social institution of higher 
education. Equity involves considerations of an ongoing array of social processes and institutions and their subsequent impact on select social groups; the ways in which such social arrangements disadvantage some groups and legitimate others. Considerations for equity call forth issues of justness and fairness as well as strategies aimed at accounting for historical lineages of inequality [emphasis in original]. (p. 2)

Finally, when faced with knowledge of these social arrangements and their effects, action can become a moral imperative (Pine \& Hilliard, 1990). As such, a concern for positive change is embedded within equity. Equity, framed as an aspirational standard to be more deeply understood through ongoing, critical analysis, then requires the move to action. As Brennan and Naidoo (2008) surmise, increased understanding of "higher education's contribution to the achievement of equity and social justice may well require both cultural change within the academic profession and new forms of relationship between institutions of higher education and the societies of which they form a part" (p. 298). This underscores that if higher education has a role in advancing social equity, so too should the institutions that comprise it. References in this analysis echo this belief, calling not only for more equity-focused inquiry on higher education but also within colleges and universities themselves. Renner and Moore (2004) suggest institutional audits while Marin and Yun (2005) advocate for educational scrutiny; in either case, the goal is not merely to seek rhetorical consistency in stated commitments to a value but instead to generate institutional alignment in the creation of equity as a particular institutional outcome.

Despite my cautious optimism about use of an equity frame for the pursuit of racial justice in higher education research and practice, it is not a cure-all nor is it an approach unchallenged by complexity. Its emancipatory potential is not a guarantee for several reasons. First, the notion of equity is not inherently progressive; its requirements will vary based on whether need or merit is of central concern (Ashley, 2014). Need would shift institutional resources toward the relatively underprivileged while merit, especially if narrowly defined, would shift institutional resources toward the relatively privileged (Liu, 2011; Orfield et al., 2005). The former would meet my understanding of justice; the latter would not. Second, equity and equality are often used interchangeably, allowing for elision of equity's emphasis on unequal distribution to achieve justice and fairness (Espinoza, 2007; Valli et al., 1997). Third, even if guided by a concern for relative need, the pursuit of equity is a complex process, particularly when undertaken collectively. Zine's (2001) investigation of the collective creation of an equity-focused policy reveals that such efforts are rife with potential for negotiation, contestation, and conflict as groups debate the realistic implications, rhetorically and practically, of different definitions of equity. Finally, the current higher education 
context of increasing public scrutiny, funding crises, and external assessment pressures constrains institutions' ability to justify and pursue values-based change even as they must continue to do so (Astin \& antonio, 2012; Campbell, 2015). Given these insights, pragmatism might suggest that racial equity is a complex and potentially unlikely goal; nevertheless, it must be pursued with "the unbelievable conviction that something must be done, that action must be taken” (D. Bell, 1991, p. 91).

\section{IMPLICATIONS}

This review suggests that while equity is not a panacea, it is a potentially productive frame for higher education research and practice, one that is relatively scarce within top-cited scholarship. Despite its complexities, there is great potential for equity concerns to influence domestic higher education research. Other scholars suggest the same. A 2012 supplement of the Review of Higher Education highlighted the productive link between an equity orientation and critical perspectives on educational research and practice. Similarly, a recent special issue of Equity and Excellence in Education acts as:

[a] call [to action] not only to push the boundaries of knowledge but also to encourage those in higher education ... to think more deeply about the ideas, language (e.g., social justice, equity, fairness, access, etc.) and patterns of thought that are often taken for granted in higher education contexts. (Patton, Shahjahan, \& Osei-Kofi, 2010, p. 268)

These patterns can be unearthed and explored through both theoretical and empirical scholarship.

The frames we use for our work are necessarily important; nevertheless, it is useful to distinguish being motivated by equity from pursuing it. Estela Bensimon (2012) and colleagues engage in this pursuit through application of the Equity Scorecard-a race-conscious, justice- and practice-oriented tool for organizational change toward equity. While it is important that this normative approach to institutional responsibility for equitable student outcomes is prevalent in the literature on equity in higher education, productive evolution of the concept and its related practice will inevitably be structured by the orientation and intentions of the scholars, activists, and practitioners who rise to equity's call. The development and examination of key tools with which to pursue equity in higher education must be more than a one-shop operation.

Finally, although studies of higher education rarely link institutional action to broader relations of power, a critical approach is required to uncover the role that higher education plays in the recreation and disruption of social inequities (Bensimon \& Bishop, 2012). Extant investigations often frame 
institutions as apolitical entities, abstracted from the larger social context, even as this research documents how concern for power and legitimacy regularly influence institutional practice (DiMaggio \& Powell, 1983; Pusser \& Marginson, 2013). Rather than a legal centric or colorblind approach that shunts systemic analysis of institutional contributions to the endurance of racial inequity, the task is to uncover the ideological, social, political, and economic factors that help to reproduce racialized power relations and inequities (Bonilla-Silva, 2006; García, 1999). Critical attention to social discourses of race-neutrality, colorblindness, inclusion, and loosely multidimensional diversity can uncover dependence on common sense notions that inhibit the critical reflection that can lead to deep institutional change.

Still, as Archer (2007) warns, equity is not immune to rhetorical abuse; work done under its umbrella must be subjected to critical inquiry. Realization of equity's promise in higher education requires critical examination of equity-framed efforts. Interrogation of the structural effects of race and racism, particularly as embodied in the norms and effects of problem framing, practice, and research, is part of what Anderson (2012) calls the "fundamental policy challenge" (p. 140). Rather than after-the-fact critiques for which critical scholars are rightfully known, this policy challenge necessitates interactive and proactive engagement of the range of stakeholders whose thoughts and actions influence the direction of higher education.

\section{Conclusion}

This paper offers a critical literature review of diversity and equity frames in higher education research. It is guided by a set of research questions that center where and how race, ethnicity, and the inequities faced by minoritized populations are addressed in top-cited scholarship. Findings indicate that the prevalence of race or justice-neutral rhetoric in diversity discourse in higher education prevents a serious investigation of race, racism, and racial inequities in minoritized students' college experiences and outcomes (S. R. Harper, 2012; Morfin et al., 2006; Winkle-Wagner \& Locks, 2013). It also inhibits productive work toward reducing race-inflected institutional inequities (Chesler \& Crowfoot, 1989). Equity, conversely, offers an opportunity to re-inflect discourse and practice in higher education with attention to-and an orientation toward-institutional responsibility for minoritized students' experiences and outcomes.

\section{REFERENCES}

Aguirre, A., \& Martinez, R. (2003). The diversity rationale in higher education: An overview of the contemporary legal context. Social Justice, 30(1), 138-152. Retrieved from http://www.jstor.org/stable/29768169 
Ahmed, S. (2012). On being included: Racism and diversity in institutional life. Durham, NC: Duke University Press.

Allen, W. R. (2005). A forward glance in a mirror: Diversity challenged-access, equity, and success in higher education. Educational Researcher, 34(7), 18-23. doi:10.3102/0013189X034007018

Allen, W. R., Teranishi, R., Dinwiddie, G., \& Gonzalez, G. (2000). Knocking at freedom's door: Race, equity and affirmative action in U.S. higher education. Journal of Negro Education, 69(1/2), 3-11. doi:10.2307/3343241

Alon, S., \& Tienda, M. (2007). Diversity, opportunity, and the shifting meritocracy in higher education. American Sociological Review, 72(4), 487-511. doi:10.1177/000312240707200401

Ancheta, A. N. (2007). Antidiscrimination law and race-conscious recruitment, retention, and financial aid policies in higher education. In G. Orfield, P. Marin, S. M. Flores, \& L. M. Garces (Ed.), Charting the future of college affirmative action: Legal victories, continuing attacks, and new research (pp. 15-34). Los Angeles, CA: The Civil Rights Project at UCLA.

Andersen, M. L. (2001). Restructuring for whom? Race, class, gender, and the ideology of invisibility. Sociological Forum, 16(2), 181-201. doi:10.2307/685062

Anderson, G. M. (2005). In the name of diversity: Education and the commoditization and consumption of race in the United States. The Urban Review, 37(5), 399-423. doi:10.1007/s11256-005-0017-z

Anderson, G. M. (2012). Equity and critical policy analysis in higher education: A bridge still too far. Review of Higher Education, 36(1), 133-142. doi:10.1353/ rhe.2012.0051

Archer, L. (2007). Diversity, equality and higher education: A critical reflection on the $\mathrm{ab} /$ uses of equity discourse within widening participation. Teaching in Higher Education, 12(5-6), 635-653. doi:10.1080/13562510701595325

Ashley, S. R. (2014). Is the inequality equitable? An examination of the distributive equity of philanthropic grants to rural communities. Administration \& Society, 46(6), 684-706. doi:10.1177/0095399712469196

Astin, A. W., \& antonio, a. 1. (2012). Assessment for excellence: The philosophy and practice of assessment and evaluation in higher education (2nd ed.). Lanham, MD: Rowman \& Littlefield.

Astin, A. W., \& Oseguera, L. (2004). The declining “equity" of American higher education. Review of Higher Education, 27(3), 321-341. doi:10.1353/rhe.2004.0001

Banks, R. R. (2007). Race-conscious affirmative action and race-neutral policies in the aftermath of the Michigan cases. In G. Orfield, P. Marin, S. M. Flores, \& L. M. Garces (Ed.), Charting the future of college affirmative action: Legal victories, continuing attacks, and new research (pp. 35-56). Los Angeles, CA: The Civil Rights Project at UCLA.

Banning, J. H., Ahuna, L. M., \& Hughes, B. M. (2000). A study of the NASPA Journal (1967-1996): A 30-year reflection of scholarship in student affairs focusing on race and ethnicity. NASPA Journal, 38(1), 58-69. Retrieved from http:// dx.doi.org/10.2202/1949-6605.1121

Bell, D. (1976). Racial remediation: An historical perspective on current conditions. Notre Dame Law, 52(5), 5-29. Retrieved from http://scholarship.law.nd.edu/ ndlr/vol52/iss1/1 
Bell, D. (1980). Brown v. Board of Education and the interest-convergence dilemma. Harvard Law Review, 93(3), 518-533. Retrieved from http://www.jstor.org/ stable/1340546

Bell, D. (1991). Racism is here to stay: Now what? Howard Law Journal, 35, 79-93. Retrieved from http://heinonline.org/HOL/Page?handle=hein.journals/ howlj35\&g_sent $=1 \&$ collection $=$ journals\&id $=87$

Bell, D. (2003). Diversity's Distractions. Columbia law review, 103(6), 1622-1633. doi:10.2307/3593396

Bell, J. M., \& Hartmann, D. (2007). Diversity in everyday discourse: The cultural ambiguities and consequences of "happy talk". American Sociological Review, 72(6), 895-914. doi:10.1177/000312240707200603

Benhabib, S. (2000). The claims of culture: Equality and diversity in the global era. Princeton, NJ: Princeton University Press.

Bensimon, E. M. (2012). The Equity Scorecard: Theory of change. In E. M. Bensimon \& L. Malcolm (Eds.), Confronting equity issues on campus: Implementing the Equity Scorecard in theory and practice (pp. 17-44). Sterling, VA: Stylus.

Bensimon, E. M., \& Bishop, R. (2012). Introduction: Why "critical"? The need for new ways of knowing. Review of Higher Education, 36(1), 1-7. doi:10.1353/ rhe.2012.0046

Berrey, E. C. (2005). Divided over diversity: Political discourse in a Chicago neighborhood. City \& Community, 4(2), 143-170. doi:10.1111/j.15406040.2005.00109.x

Berrey, E. C. (2011). Why diversity became orthodox in higher education, and how it changed the meaning of race on campus. Critical Sociology, 37(5), 573-596. doi:10.1177/0896920510380069

Blackmore, J. (2006). Deconstructing diversity discourses in the field of educational management and leadership. Educational Management Administration \& Leadership, 34(2), 181-199. doi:10.1177/1741143206062492

Bloom Jr, L. H. (1998). Hopwood, Bakke and the future of the diversity justification. Texas Tech Law Review, 29(1), 1-73. Retrieved from http://heinonline. org/HOL/Page?handle=hein.journals/text29\&g_sent=1\&collection=journa ls\&id=11

Bonilla-Silva, E. (2006). Racism without racists: Color-blind racism and the persistence of racial inequality in America (2nd ed.). Lanham, MD: Rowman \& Littlefield.

Bowen, W. G., \& Bok, D. (1998). Shape of the river: Long-term consequences of considering race in college and university admissions. Princeton, NJ: Princeton University Press.

Bowen, W. G., Kurzweil, M. A., Tobin, E. M., \& Pichler, S. C. (2005). Equity and excellence in American higher education. Charlottesville, VA: University of Virginia Press.

Boyatzis, R. (1998). Transforming qualitative information: Thematic analysis and code development. Thousand Oaks, CA: Sage.

Brennan, J., \& Naidoo, R. (2008). Higher education and the achievement (and/or prevention) of equity and social justice. Higher Education, 56(3), 287-302. doi:10.1007/s10734-008-9127-3

Brest, P., \& Oshige, M. (1995). Affirmative action for whom? Stanford Law Review, 47, 855 -900. Retrieved from http://www.jstor.org/stable/1229177 
Brown, L. I. (2004). Diversity: The challenge for higher education. Race Ethnicity and Education, 7(1), 21-34. doi:10.1080/1361332042000187289

Brown, R. H. (2002). Overcoming educational exclusion: Is diversity an appropriate model for democratic higher education? American Behavioral Scientist, 45(7), 1061-1087. doi:10.1177/0002764202045007003

Brown v. Board of Education of Topeka, 347 U.S. 483 (1954).

Buhrke, R. A., Ben-Ezra, L. A., Hurley, M. E., \& Ruprecht, L. J. (1992). Content analysis and methodological critique of articles concerning lesbian and gay male issues in counseling journals. Journal of Counseling Psychology, 39(1), 91-99. Retrieved from http://dx.doi.org/10.1037/0022-0167.39.1.91

Campbell, C. M. (2015). Serving a different master: Assessing college educational quality for the public. In M. B. Paulsen (Ed.), Higher education: Handbook of theory and research (Vol. XXX, pp. 525-579). New York, NY: Springer.

Chang, M. J. (2002). Preservation or transformation: Where's the real educational discourse on diversity? Review of Higher Education, 25(2), 125-140. doi:10.1353/ rhe.2002.0003

Chang, M. J., Astin, A. W., \& Kim, D. (2004). Cross-racial interaction among undergraduates: Some consequences, causes, and patterns. Research in Higher Education, 45(5), 529-553. doi:10.1023/B:RIHE.0000032327.45961.33

Chang, M. J., Denson, N., Saenz, V., \& Misa, K. (2006). The educational benefits of sustaining cross-racial interaction among undergraduates. Journal of Higher Education, 77(3), 430-455. doi:10.1353/jhe.2006.0018

Charmaz, K. (2014). Constructing grounded theory: A practical guide through qualitative analysis (2nd ed.). Los Angeles, CA: Sage.

Chesler, M.A., \& Crowfoot, J. (1989). Racism in higher education I: An organizational analysis Program on Conflict Management Alternatives Working Paper Series. Ann Arbor, MI: University of Michigan.

Clancy, P., \& Goastellec, G. (2007). Exploring access and equity in higher education: Policy and performance in a comparative perspective. Higher Education Quarterly, 61(2), 136-154. doi:10.1111/j.1468-2273.2007.00343.x

Cokorinos, L. (2003). The assault on diversity: An organized challenge to racial and gender justice. Lanham, MD: Rowman \& Littlefield.

Coleman, J. (1968). The concept of equality of educational opportunity. Harvard Educational Review, 38(1), 7-22. Retrieved from http://dx.doi.org/10.17763/ haer.38.1.m3770776577415m2

Contreras, F. (2011). Achieving equity for Latino students: Expanding the pathway to higher education through public policy. New York, NY: Teachers College Press.

Cortes, K. E. (2010). Do bans on affirmative action hurt minority students? Evidence from the Texas Top 10\% Plan. Economics of Education Review, 29(6), 11101124. Retrieved from http://dx.doi.org/10.1016/j.econedurev.2010.06.004

Creamer, E. G. (1994). Gender and publications in core higher education journals. Journal of College Student Development, 35(1), 35-39. Retrieved from http:// eric.ed.gov/?id=EJ478906

Davis, L. R. (2002). Racial diversity in higher education: Ingredients for success and failure. Journal of Applied Behavioral Science, 38(2), 137-155. doi:10.1177/00286302038002001 
Delgado, R. (1984). The imperial scholar: Reflections on a review of civil rights literature. University of Pennsylvania Law Review, 132(3), 561-578. Retrieved from http://www.jstor.org/stable/3311882

Delgado, R. (1992). The imperial scholar revisited: How to marginalize outsider writing, ten years later. University of Pennsylvania Law Review, 140(4), 1349-1372. Retrieved from http://www.jstor.org/stable/3312406

Denzin, N. K., \& Lincoln, Y. S. (2008). Introduction: The discipline and practice of qualitative research In N. K. Denzin \& Y. S. Lincoln (Eds.), Collecting and interpreting qualitative material (3rd ed.). Los Angeles, CA: Sage.

Dickson, L. M. (2006). Does ending affirmative action in college admissions lower the percent of minority students applying to college? Economics of Education Review, 25(1), 109-119. Retrieved from http://dx.doi.org/10.1016/j.econedurev.2004.11.005

DiMaggio, P. J., \& Powell, W. W. (1983). The iron cage revisited: Institutional isomorphism and collective rationality in organizational fields. American Sociological Review, 48(2), 147-160. Retrieved from http://www.jstor.org/stable/2095101

Donaldson, J. F., \& Townsend, B. K. (2007). Higher education journals' discourse about adult undergraduate students. Journal of Higher Education, 78(1), 27-50. doi:10.1353/jhe.2007.0001

Dowd, A. C., \& Bensimon, E. M. (2015). Engaging the "race question": Accountability and equity in U.S. higher education. New York, NY: Teachers College Press.

Dumas-Hines, F. A., Cochran, L. L., \& Williams, E. U. (2001). Promoting diversity: Recommendations for recruitment and retention of minorities in higher education. College Student Journal, 35(3), 433-441. Retrieved from https:// www.questia.com/library/journal/1G1-80744656/promoting-diversityrecommedations-for-recruitment

Epple, D., Romano, R., \& Sieg, H. (2008). Diversity and affirmative action in higher education. Journal of Public Economic Theory, 10(4), 475-501. doi: 10.1111/j.1467-9779.2008.00373.x

Espinoza, O. (2007). Solving the equity-equality conceptual dilemma: A new model for analysis of the educational process. Educational Researcher, 49(4), 343-363. doi:10.1080/00131880701717198

Fereday, J., \& Muir-Cochrane, E. (2006). Demonstrating rigor using thematic analysis: A hybrid approach of inductive and deductive coding and theme development. International Journal of Qualitative Methods, 5(1), 80-92. doi:10.1177/160940690600500107

Fisher v. University of Texas at Austin, 631 F.3d 213 (5th Cir. 2011).

Fisher v. University of Texas at Austin, 570 U. S. (2013).

Fisher v. University of Texas at Austin, 579 U. S. __ (2016).

Fisher v. University of Texas at Austin, 645 F.Supp.2d 587 (W.D. Tex. 2009).

Gansemer-Topf, A. M., \& Schuh, J. H. (2006). Institutional selectivity and institutional expenditures: Examining organizational factors that contribute to retention and graduation. Research in Higher education, 47(6), 613-642. doi:10.1007/ s11162-006-9009-4

Garces, L. M. (2012). Racial diversity, legitimacy, and the citizenry: The impactof affirmative action bans on graduate school enrollment. Review of Higher Education, 36(1), 93-132. doi:10.1353/rhe.2012.0050 
Garces, L. M., \& Jayakumar, U. M. (2014). Dynamic diversity toward a contextual understanding of critical mass. Educational Researcher, 43(3), 115-124. doi:10.3102/0013189X14529814

García, A. M. (1999). Multiculturalism: An 'as if' phenomenon. International Journal of Qualitative Studies in Education, 12(3), 299-310. doi:10.1080/095183999236150

Garcia-Penalosa, C., \& Wälde, K. (2000). Efficiency and equity effects of subsidies to higher education. Oxford Economic Papers, 52(4), 702-722. Retrieved from http://www.jstor.org/stable/3488665

Gillborn, D. (2005). Education policy as an act of white supremacy: Whiteness, critical race theory and education reform. Journal of Education Policy, 20(4), 485-505. doi:10.1080/02680930500132346

Gillborn, D., \& Youdell, D. (2000). Rationing education: Policy, practice, reform, and equity. Buckingham, England, and Philadelphia, PA: Open University Press.

Grutter v. Bollinger, 539 U.S. 306 (2003).

Gurin, P., Dey, E. L., Hurtado, S., \& Gurin, G. (2002). Diversity and higher education: Theory and impact on educational outcomes. Harvard Educational Review, 72(3), 330-367. Retrieved from http://dx.doi.org/10.17763/ haer.72.3.01151786u134n051

Hale, F. W. (Ed.) (2004). What makes racial diversity work in higher education. Sterling, VA: Stylus.

Halverson, L. R., Graham, C. R., Spring, K. J., \& Drysdale, J. S. (2012). An analysis of high impact scholarship and publication trends in blended learning. Distance Education, 33(3), 381-413. Retrieved from http://dx.doi.org/10.1080/015879 19.2012.723166

Halverson, L. R., Graham, C. R., Spring, K. J., Drysdale, J. S., \& Henrie, C. R. (2014). A thematic analysis of the most highly cited scholarship in the first decade of blended learning research. The Internet and Higher Education, 20, 20-34. Retrieved from http://dx.doi.org/10.1016/j.iheduc.2013.09.004

Harper, S., \& Reskin, B. (2005). Affirmative action at school and on the job. Annual Review of Sociology, 31, 357-379. Retrieved from http://www.jstor.org/ stable/29737724

Harper, S. R. (2012). Race without racism: How higher education researchers minimize racist institutional norms. Review of Higher Education, 36 (1, Supplement), 9-29. doi: 10.1353/rhe.2012.0047

Harper, S. R., \& Hurtado, S. (2007). Nine themes in campus racial climates and implications for institutional transformation. New Directions for Student Services, 120, 7-24. doi:10.1002/ss.254

Harper, S. R., Patton, L. D., \& Wooden, O. S. (2009). Access and equity for African American students in higher education: A critical race historical analysis of policy efforts. The Journal of Higher Education, 80(4), 389-414. doi: 10.1353/ jhe.0.0052

Hess, D. E. (2009). Controversy in the classroom: The democratic power of discussion. New York, NY: Routledge.

Hinrichs, P. (2012). The effects of affirmative action bans on college enrollment, educational attainment, and the demographic composition of universities. Review of Economics and Statistics, 94(3), 712-722.doi:10.1162/REST_a_00170 
Horvat, E. M. (2001). Understanding equity and access in higher education: The potential contribution of Pierre Bourdieu. In J. C. Smart (Ed.), Higher education: Handbook of theory and research (Vol. XVI, pp. 195-238). New York, NY: Agathon Press.

Hurtado, S. (2007). Linking diversity with the educational and civic missions of higher education. Review of Higher Education, 30(2), 185-196. doi: 10.1353/ rhe.2006.0070

Hurtado, S., Milem, J. F., Clayton-Pedersen, A. R., \& Allen, W. R. (1998). Enhancing campus climates for racial/ethnic diversity: Educational policy and practice. Review of Higher Education, 21(3), 279-302. doi:10.1353/rhe.1998.0003

Ibarra, R. A. (2001). Beyond affirmative action: Reframing the context of higher education. Madison, WI: University of Wisconsin Press.

Iverson, S. V. D. (2012). Constructing outsiders: The discursive framing of access in university diversity policies. Review of Higher Education, 35(2), 149-177. doi:10.1353/rhe.2012.0013

Jayakumar, U. M. (2008). Can higher education meet the needs of an increasingly diverse and global society? Campus diversity and cross-cultural workforce competencies. Harvard Educational Review, 78(4), 615-651. Retrieved from http://dx.doi.org/10.17763/haer.78.4.b60031p350276699

Karen, D. (2002). Changes in access to higher education in the United States: 19801992. Sociology of Education, 75(3), 191-210. doi:10.2307/3090265

Kelly, E., \& Dobbin, F. (1998). How affirmative action became diversity management: Employer response to antidiscrimination law, 1961 to 1996. American Behavioral Scientist, 41(7), 960-984. doi:10.1177/0002764298041007008

Kidder, W. C. (2000). Affirmative action in higher education: Recent developments in litigation, admissions and diversity research. Berkeley La Raza Law Journal, 12, 173-230. Retrieved from http://heinonline.org/HOL/ LandingPage?handle $=$ hein.journals/berklarlj12\&div=14\&id=\&page $=$

Kincheloe, J., \& McLaren, P. (2011). Rethinking critical theory and qualitative research. In K. Hayes, S. R. Steinberg, \& K. Tobin (Eds.), Key works in critical pedagogy (Vol. 32, pp. 285-326). Dordrecht, Netherlands: Sense Publishers.

Kuh, G. D., \& Bursky, M. (1980). Knowledge dissemination by publication in student affairs: Who publishes what where? Journal of College Student Personnel, 21(5), 387-393. Retrieved from http://eric.ed.gov/?id=EJ231729

Liu, A. (2011). Unraveling the myth of meritocracy within the context of US higher education. Higher Education, 62(4), 383-397. doi:10.1007/s10734-010-9394-7

Long, M. C. (2007). Affirmative action and its alternatives in public universities: What do we know? Public Administration Review, 76(2), 315-330. doi:10.1111/j.15406210.2007.00715.x

Lynch, C. (2006). Critical interpretation of interwar peace movements. In D. Yanow \& P. Schwartz-Shea (Eds.), Interpretation and method: Empirical research methods and the interpretive turn (pp. 291-299). London, England, and New York, NY: M.E. Sharpe.

Marin, P., \& Yun, J. T. (2005). From strict scrutiny to educational scrutiny: A new vision for higher education policy and research. In G. Orfield, P. Marin, \& C. L. Horn (Eds.), Higher Education and the color line: College access, racial equity, and social change (pp. 197-218). Cambridge, MA: Harvard University Press. 
Mars, M. M., \& Rios-Aguilar, C. (2010). Academic entrepreneurship (re)defined: Significance and implications for the scholarship of higher education. Higher Education, 59(4), 441-460. doi:10.1007/s10734-009-9258-1

Melguizo, T. (2008). Quality matters: Assessing the impact of attending more selective institutions on college completion rates of minorities. Research in Higher education, 49(3), 214-236. doi:10.1007/s11162-007-9076-1

Meyer, R. (2016). Independent and unequal: How independent educational evaluations provide less than equal educational opportunity to students with disabilities. Boston University Public Interest Law Journal, 25(1), 75-100. Retrieved from http://heinonline.org/HOL/Page?handle=hein.journals/bupi25\&g_sent $=1 \&$ collection $=$ journals\&id $=77$

Moran, R. F. (2006). Of doubt and diversity: The future of affirmative action in higher education. Ohio State Law Journal, 67, 201-243. Retrieved from http://heinonline.org/HOL/LandingPage?handle=hein.journals/ ohslj67\&div $=17 \&$ id $=$ \&page $=$

Morfin, O. J., Perez, V.H., Parker, L., Lynn, M., \& Arrona, J. (2006). Hiding the politically obvious: A critical race theory preview of diversity as racial neutrality in higher education. Educational Policy, 20(1), 249-270. doi:10.1177/0895904805285785

Musil, C. M. (1996). The maturing of diversity initiatives on American campuses. American Behavioral Scientist, 40(2), 222-232. doi:10.1177/0002764296040002013

Musil, C. M., Garcia, M., Hudgins, C. A., Nettles, M. T., Sedlacek, W. E., \& Smith, D. G. (1999). To form a more perfect union: Campus diversity initiatives. Understanding the Difference Diversity Makes: Assessing Campus Diversity Initiatives. Washington, D.C.: Association of American Colleges and Universities.

National Center for Education Statistics. (2012). Digest of Education Statistics: 2011. Retrieved from Washington, DC: http://nces.ed.gov/programs/digest/d11/ index.asp

Ng, R. (2003). Toward an integrative approach to equity in education. In P. Trifonas (Ed.), Pedagogies of difference: Rethinking education for social change (pp. 206-213). New York, NY: RoutledgeFalmer.

Orfield, G., Marin, P., Flores, S. M., \& Garces, L. M. (2007). Charting the future of college affirmative action: Legal victories, continuing attacks, and new research. Los Angeles, CA: The Civil Rights Project at UCLA.

Orfield, G., Marin, P., \& Horn, C. L. (2005). Higher Education and the color line: College access, racial equity, and social change. Cambridge, MA: Harvard University Press.

Orfield, G., \& Miller, E. (Eds.). (1998). Chilling admissions: The affirmative action crisis and the search for alternatives. Cambridge, MA: Harvard Education Publishing Group.

Oswick, C. (2010). The social construction of diversity, equality and inclusion. In G. Healy, G. Kirton, \& M. Noon (Eds.), Equality, inequalities and diversity: Contemporary challenges and strategies (pp. 18-36). New York, NY: Palgrave Macmillan.

Paradise, B. (2011). Racially transcendent diversity. University of Louisville Law Review, 50, 415-489. Retrieved from http://heinonline.org/HOL/Page?handle=hein. journals/branlaj50\&g_sent $=1 \&$ collection=journals\&id $=421$ 
Pasque, P. A., Carducci, R., Kuntz, A. M., \& Gildersleeve, R. E. (2012). Qualitative inquiry for equity in higher education: Methodological innovations, implications, and interventions. In K. Ward \& L. E. Wolf-Wendel (Eds.), ASHE higher education report (Vol. 37, pp. 1-15). San Francisco, CA: Wiley.

Patton, L. D., Shahjahan, R. A., \& Osei-Kofi, N. (2010). Introduction to the "Emergent Approaches to Diversity and Social Justice in Higher Education" special issue. Equity \& Excellence in Education, 43(3), 265-278. doi:10.1080/106656 84.2010 .496692

Perna, L. W., Milem, J., Gerald, D., Baum, E., Rowan, H., \& Hutchens, N. (2006). The status of equity for Black undergraduates in public higher education in the south: Still separate and unequal. Research in Higher education, 47(2), 197-228. doi:10.1007/s11162-005-8886-2

Pine, G. J., \& Hilliard, A. G. (1990). Rx for racism: Imperatives for America's schools. Phi Delta Kappan, 71(8), 593-600. Retrieved from http://0-www.jstor.org.libus. csd.mu.edu/stable/20404226

Pinel, E. C., Warner, L. R., \& Chua, P. P. (2005). Getting there is only half the battle: Stigma consciousness and maintaining diversity in higher education. Journal of Social Issues, 61(3), 481-506. doi:10.1111/j.1540-4560.2005.00417.x

Prasad, P., \& Mills, A. J. (1997). From showcase to shadow: Understanding the dilemmas of workplace diversity. In P. Prasad, A. J. Mills, M. Elmes, \& A. Prasad (Eds.), Managing the organizational melting pot: Dilemmas of workplace diversity (pp. 3-27). Thousand Oaks, CA: Sage.

Pursley, G. B. (2003). Thinking diversity, rethinking race: Toward a transformative concept of diversity in higher education. Texas Law Review, 82, 153-199. Retrieved from http://heinonline.org/HOL/LandingPage?handle=hein.journals/ tlr82\&div $=15 \&$ \&id $=$ \&page $=$

Pusser, B., \& Marginson, S. (2013). University rankings in critical perspective. Journal of Higher Education, 84(4), 544-568. doi:10.1353/jhe.2013.0022

Quaye, S. J., \& Harper, S. R. (Ed.) (2014). Student engagement in higher education: Theoretical perspectives and practical approaches for diverse populations (2nd ed.). New York, NY, and London, England: Routledge.

Regents of the University of California v. Bakke, 438 U.S. 265 (1978).

Renner, K. E., \& Moore, T. (2004). The more things change, the more they stay the same: The elusive search for racial equity in higher education. Analyses of Social Issue and Public Policy, 4(1), 227-241. doi: 10.1111/j.1530-2415.2004.00045.x

Rose, D. (2015). Regulating opportunity: Title IX and the birth of gender-conscious higher education policy. Journal of Policy History, 27(1), 157-183. Retrieved from https://doi.org/10.1017/S0898030614000396

Ryu, M. (2009) Minorities in higher education: 2009 supplement. Twenty-third status report. Washington, DC: American Council on Education.

Saldaña, J. (2009). The coding manual for qualitative researchers (2nd ed.). Los Angeles, CA: Sage.

Sewell, W. H. (1971). Inequality of opportunity for higher education. American Sociological Review, 36(5), 793-809. Retrieved from http://www.jstor.org/ stable/2093667 
Shabazz, A. (2004). Advancing democracy: African Americans and the struggle for access and equity in higher education in Texas. Chapel Hill, NC: University of North Carolina Press.

Skrentny, J. D. (2002). The minority rights revolution. Cambridge, MA: Harvard University Press.

Swan, E. (2010). Commodity diversity: Smiling faces as a strategy of containment. Organization, 17(1), 77-100. doi:10.1177/1350508409350043

Taylor, S. (1997). Critical policy analysis: Exploring contexts, texts and consequences. Discourse: Studies in the Cultural Politics of Education, 18(1), 23-35. doi:10.1080/0159630970180102

Teranishi, R. T., Allen, W., \& Solorzano, D. (2004). Opportunity at the crossroads: Racial inequality, school segregation, and higher education in California. Teachers College Record, 106(11), 2224-2245. Retrieved from http://eric. ed.gov/?id=EJ687600

Tienda, M. (2013). Diversity $\neq$ inclusion promoting integration in higher education. Educational Researcher, 42(9), 467-475. Retrieved from 10.3102/0013189X13516164

Tienda, M., Leicht, K. T., Sullivan, T., Maltese, M., \& Lloyd, K. (2003). Closing the gap?: Admissions and enrollments at the Texas public flagships before and after affirmative action (Working Paper 2003-01). Retrieved from Princeton, NJ: http://theop.princeton.edu/reports/wp/closing_the_gap.pdf

Tierney, W. G. (1997). The parameters of affirmative action: Equity and excellence in the academy. Review of Educational Research, 67(2), 165-196. doi:10.3102/00346543067002165

Tisdell, E. (2007). In the new millennium: The role of spirituality and the cultural imagination in dealing with diversity and equity in the higher education classroom. Teachers College Record, 109(3), 531-560. Retrieved from http:// www.tcrecord.org/Content.asp?ContentID $=12223$

Townsend, B. K., Donaldson, J., \& Wilson, T. (2009). Marginal or monumental? Visibility of community colleges in selected higher-education journals. Community College Journal of Research and Practice, 33(9), 708-720. Retrieved from http://dx.doi.org/10.1080/10668920903022441

Turner, C. S. V., González, J. C., \& Wood, J. L. (2011). Faculty of color in academe: What 20 years of literature tells us. In S. R. Harper \& J. F. L. Jackson (Eds.), Introduction to American higher education (pp. 41-73). New York, NY, and London, England: Routledge.

U.S. Department of Education. (n.d.). Table 5.2A. Percentage distribution of undergraduates, by race/ethnicity and selected institutional and student characteristics: 2003-04. National Postsecondary Student Aid Study (NPSAS:04). Washington, DC: National Center for Education Statistics.

Valli, L., Cooper, D., \& Frankes, L. (1997). Professional development schools and equity: A critical analysis of rhetoric and research. Review of Research in Education, 22, 251-304. Retrieved from http://www.jstor.org/stable/1167377

Ward, N. L. (2006). Improving equity and access for low-income and minority youth into institutions of higher education. Urban Education, 41(1), 50-70. doi:10.1177/0042085905282253 
Winbush, R. A. (2004). Brief meditation on diversity and "duhversity". In F. W. Hale (Ed.), What makes racial diversity work in higher education (pp. 33-37). Sterling, VA: Stylus.

Winkle-Wagner, R., \& Locks, A. M. (Eds.). (2013). Diversity and inclusion on campus: Supporting racially and ethnically underrepresented students. New York, NY: Routledge.

Yosso, T. J., Parker, L., Solórzano, D. G., \& Lynn, M. (2004). From Jim Crow to affirmative action and back again: A critical race discussion of racialized rationales and access to higher education. Review of Research in Education, 28, 1-25. Retrieved from http://www.jstor.org/stable/3568134

Zine, J. (2001). Negotiating equity: The dynamics of minority community engagement in constructing inclusive education policy. Cambridge Journal of Education, 31(2), 239-269. Retrieved from http://dx.doi.org/10.1080/0305764012006164 